\title{
Provinces optimistic for health accord talks
}

A new health accord will top the agenda of talks between federal, provincial and territorial health ministers next month.

The Jan. 21 meeting in Vancouver will be the first test of what the federal Liberals have promised will be an improved partnership on health after a decade of erosion under the former Conservative government. As part of this partnership, the Liberals have committed to negotiate a new long-term funding agreement to replace the lapsed 2004 Health Accord, which boosted federal health transfers to the provinces and territories by $\$ 41$ billion over a decade.

Provincial health ministers say they are optimistic for a new era of collaboration following initial talks with Federal Health Minister Dr. Jane Philpott.

"We have been clear about the need for a true partner at the health care table and I am confident that we have that," says Ontario Health Minister Dr. Eric Hoskins. "It is reassuring to know that we have a federal government that's interested in working with us."

This month, deputy ministers of health from across the country will meet to discuss priorities associated with the new accord. According to British Columbia Health Minister Terry Lake, the main goal will be to reverse changes the former Conservative government made to federal health transfers.

"The previous government changed the formula to a strictly per capita model which does not recognize that as you age the cost of health care climbs dramatically," Lake explains. (Under this arrangement, have-not provinces with relatively older, poorer and smaller populations stand to lose $\$ 16.5$ billion by 2019 , according to the Council of the Federation.) "We've urged the federal government to consider a needs-based formula that recognizes that older citizens require more extensive health care."

The provinces and territories will also ask Ottawa to increase the Canada

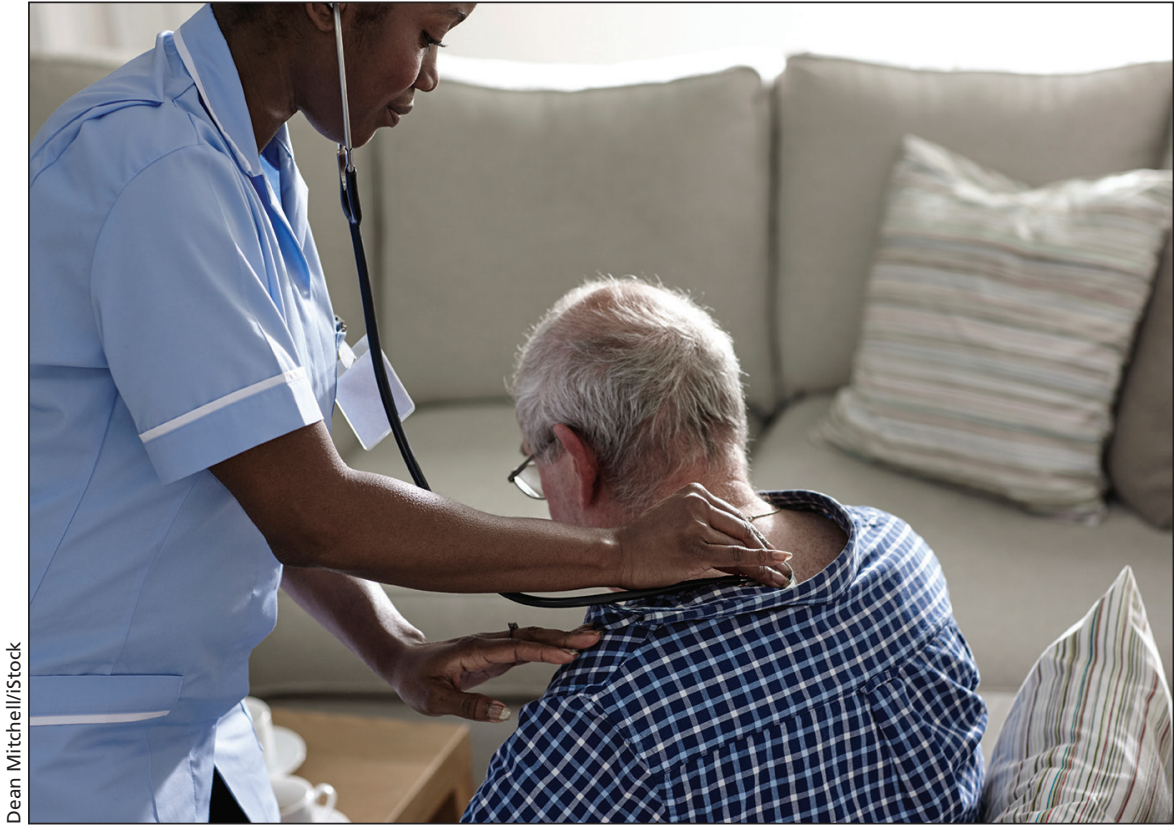

Provinces with older populations should receive a bigger share of federal health dollars to help deliver services like home care, say health ministers.

Health Transfer to cover at least $25 \%$ of all health care spending. (In BC, for example, federal transfers currently cover about $20 \%$ of health care costs.) In a departure from previous negotiations, however, the provinces don't expect to see the federal government commit to increasing transfers by $6 \%$ annually, says Lake.

"We as provinces aren't increasing our budgets by $6 \%$ year over year because we know that's not sustainable," Lake says. "We have to recognize we need sustainability but we need some catch up as well."

Some provincial health ministers, including Alberta's Sarah Hoffman, stressed the importance of predictable funding, regardless of the sum. "My main goal is to ensure we have a strong federal partner to provide stable and reliable funding going forward," she says.

But with little indication of what the federal government envisions for the new accord, some provinces remain wary of incursion on their jurisdiction. "It is important that any new health accord allows us to continue to innovate in how health services are delivered to our residents," says Eric Eggertson, a spokesperson for Saskatchewan's Ministry of Health. "Federal initiatives which do not align with provincial and territorial priorities and capacity would be counterproductive."

Although Prime Minister Justin Trudeau's campaign platform, Philpott's mandate and the Governor General's recent speech from the throne don't provide any specifics, the 2014 Biennial Liberal Convention in Montréal resolved that a future accord should include "measurable outcomes including cost-effectiveness, efficiency and timely access to care."

It remains to be seen if Trudeau will take a more active role in enforcing the Canada Health Act, says Colleen Flood, Ottawa University Research Chair in Health Law and Policy. If that's the case, the new partnership with the provinces is unlikely to remain collegial for long.

"To actually enforce the Canada Health Act would probably cause some 
conflict with Saskatchewan, which is now allowing private payment for MRIs, and Quebec, which is proposing to allow extra-billing," Flood says.

Physician-assisted suicide will be another controversial topic at the January talks, says Lake. "Ontario is already leading a provincial-territorial working group, and our own ministry has done a little ground work, including an environmental scan of what other jurisdic- tions have done," he explains. However, "we're really seeking the lead of the federal government on that."

The provinces also expect more support for harm-reduction strategies under the federal Liberals, says Lake. "Whereas the former government was putting roadblocks to continuing or expanding safe injection sites, I'm optimistic the new government will use science to make these kinds of decisions."
Conversely, it's unlikely that the legalization of marijuana will factor into discussions next month. Trudeau tasked the federal health minister with creating a federal-provincial-territorial task force with input from public health experts, "but nonmedical marijuana isn't really a health issue," says Lake. "It's a justice issue." — Lauren Vogel, CMAJ

CMAJ 2016. DOI:10.1503/cmaj.109-5206 